\title{
Disabled people in housing estates
}

\author{
Kamil Rawski \\ https://orcid.org/0000-0002-3845-4556 \\ e-mail:k.rawski@pb.edu.pl
}

Faculty of Architecture, Bialystok University of Technology

\begin{abstract}
Much attention is paid to adapting public buildings or transport for the disabled. Not much, however, to spaces where the journey to a given destination begins. The path that has to be walked from the apartment until reaching public transport can significantly hinder the lives of people with reduced mobility. A housing estate is also a place where people spend a large part of their free time. Therefore, in order not to exclude disabled people from social life, designing such places in an accessible way is extremely important. And exactly this issue was raised in this article.
\end{abstract}

Keywords: accessibility, universal design, people with disabilities, disabled, housing estate

\section{Introduction}

Mutual contacts of people are shaping the community, so the accessibility of place of residence is an important factor of social integration. The lack of proper adaptation of a commonplace of residence can exclude many people from social life [Pawłowska 2001]. It is estimated that in Poland alone, about $12.2 \%$ of the population is struggling with various dysfunctions [Adach-Stankiewicz et al. 2012],which means that the issue of adapting the environment for such people should not be ignored. An additional problem turns out to be the global growth trend of people with disabilities [Złowodzki 2008].

Designing a space accessible to disabled people, apart from being guided by the law, requires knowledge of ergonomics related to the physical properties of disabled people [Jasiak and Swereda 2009]. Thanks to this, it is possible to adjust the elements of a given area so that they are most adapted to the needs of such people. They are related to, among others with effortless movement and overcoming both technical and architectural barriers [eBIFRON 2012]. The main matter should be the needs of people in wheelchairs and people with visual impairments (including the blind) because they have the greatest difficulties with effortless movement in a given space. The elderly are another group with reduced physically agility that cannot be ignored. Given the aging tendency of society as a result of the demographic decline and the high rate of emigration, many people may be left unsupervised in the future. In the case of poor accessibility of space, this will mean significant difficulties for them in moving or even limiting their living space to the limits of the apartment.

Therefore, regardless of the initial concept, the project should include the need to comply with regulations and standards as well as matters related to ergonomics or OSH. Among the basic provisions that set out the minimum requirements are:

- Act - Building Law of 7 July 1994 (OJ 1994 No. 89 item 414 with later amendments),

- Regulation of the Minister of Infrastructure of 12 April 2002 on the technical conditions that should be met by buildings and their location (OJ 2002 No. 75 item 690, with later amendments),

- Standards related to specific solutions depending on the function [Ujma-Wąsowicz 2005].

It should be emphasized, however, that ergonomic issues are not always included there. By examining the interrelationships between a man and his environment, it is possible to determine more accurately his mobility space, and as a consequence also the needs and functional capabilities of a disabled person [Błądek 2003]. Therefore, the above issues should be supplemented with other specialist literature, such as the Neufert 
architectural design manual [Neufert 2011] or various publications related to universal design. It can be found there many dimensions obtained based on anthropometric data.

The accessibility of the multi-family residential buildings, as J. Pallado [2007] rightly points out in his book, is also largely associated with their location, and hence, the topography of the place, green areas and buildings existing there, ways of arrival, conservation and environmental conditions, as well as urban guidelines or spatial context.

\section{Material and methods}

The text concern the issue of housing estate design in an accessible way to people with special needs, such as people with disabilities and the elderly. Based on the literature on the subject, legal acts and accessibility standards, parameters that should be considered when designing such spaces have been characterized. A set of guidelines was also developed to help designers plan the availability of housing estates. In the studies, such spaces had been treated as attending the communication functions with the rest of the city and as a space with recreational and social function.

\section{Results and discussion}

\section{Neighborhood space}

When moving on the housing estate, the situation when it is necessary to overcome height differences is almost unavoidable. The consequence of this state of affairs is the need to use stairs. This is the reason for limiting access to many places. Studies show that this is a barrier for nearly $30 \%$ of the population [Ujma-Wąsowicz 2005], so not just for people classified as disabled.

However, before the detailed parameters related to the design of stairs and ramps will be quoted, it is worth to be familiar with the general principles of conduct when planning availability in a given area. Wherever possible, the design of stairs (in particular, single steps) and ramps should be avoided in favor of gentler slopes over longer sections. To allow disabled people to move effortless, the value of such longitudinal drops should be limited to a maximum of $5 \%$, because larger inclines significantly impede wheelchair travel. However, it is recommended that the transverse fall never exceeds $2 \%$. To ensure safety, the surface should be even and rough enough to exclude the possibility of tripping or slipping. Besides, when designing surfaces there should be taken into account such features as hardness, absorbability, and elasticity [Czarnecki and Siemiński 2004].

The main pedestrian routes should be wide enough to allow free movement of people moving in both directions. The determinant, in this case, is once again the size of the wheelchair. It is assumed that the width of $180 \mathrm{~cm}$ is sufficient to enable two trolleys to run side by side. However, this number should be taken as the minimum value. A width of $200 \mathrm{~cm}$ or more are also used [Wysocki 2012], to provide greater comfort for pavements where there is increased pedestrian traffic. The optimal value of other pedestrian routes is $150 \mathrm{~cm}$, which means that people in wheelchairs can easily maneuver. However, narrower walkways (like $120 \mathrm{~cm}$ wide) are also allowed - if we provide there maneuvering spaces of 150x150 cm, at least every $20 \mathrm{~m}$ (Fig. 1); and $90 \mathrm{~cm}$ - if the length of such narrowing does not exceed $150 \mathrm{~cm}$ [Kowalski 2010]. The last case usually occurs when there are any items of equipment on the path. It is also worth noting that the aforementioned numbers refer to the usable width, which means the space after deducting such elements and the legroom of potential users of benches. However, the roads leading to the entrances of buildings should be at least $150 \mathrm{~cm}$ wide [Kowalski 2010]. The good practice is to mark the edge of the road so that it contrasts with the adjacent ground. It should be also taken into consideration the height of communication routes, which should be at least $220 \mathrm{~cm}$. However, if for some reason some items of equipment are below this value, they should be marked by a contrasting warning threshold [Kowlaski 2011]. 


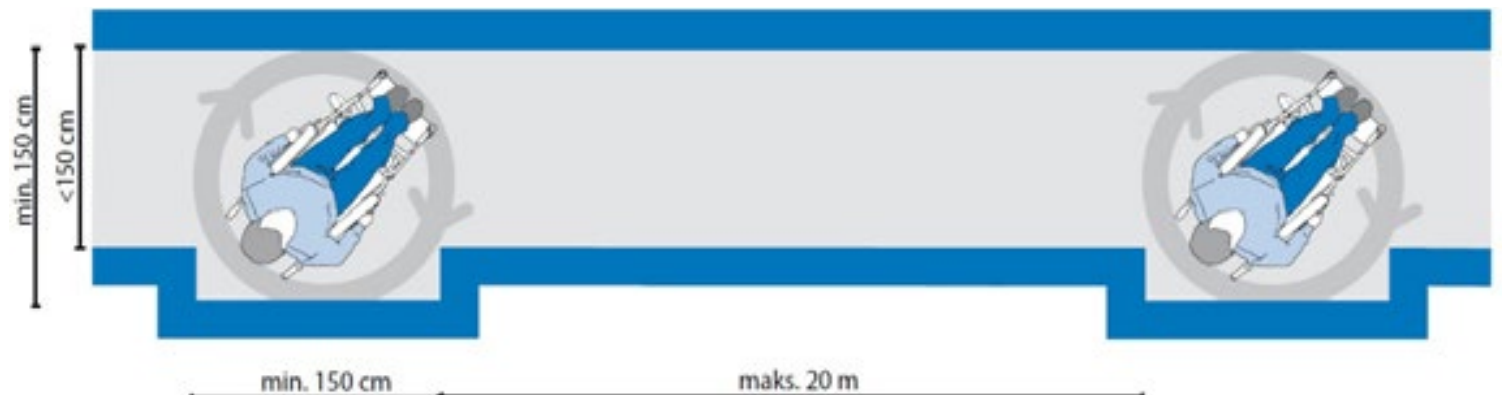

Fig. 1. Dimensions of communication paths (source: Kowalski 2010)

Properly designed stairs significantly improve the safety and comfort of use, especially for people with limited mobility. The average length of a human step is, in this case, a value that should be guided in the design. Thanks to this knowledge it is possible to apply a given formula:

$$
2 h+s=60-65 \mathrm{~cm}
$$

[RMI §68 ust. 4]

This means that the double-height of the single-step added to its width should be as much as the mentioned average step length. The number of steps in the run should be a maximum of 10 , but if the difference in levels requires more, a proper landing should be used [RMI $\S 68$ paragraph 1]. Its length in the case of multi-family residential buildings should be at least $150 \mathrm{~cm}$, while this size in the case of terrain stairs is not specified in the regulations. However, if it is possible, due to the improvement of the comfort of use, their minimum values should be assumed analogous to multi-family residential buildings. It is recommended that the number of steps will have been odd (and not less than 3). The width of the steps of the terrain stairs and at the main entrances to buildings should be $\min .35 \mathrm{~cm}$. Step height considered comfortable to use is about $15-17 \mathrm{~cm}$, while a lower value is considered more convenient. M. Wysocki in Accessibility standards for the city of Gdynia recommends their height even at $12 \mathrm{~cm}$ for added comfort. The surface of the steps should be protected against slipping, especially their edges. Stairs at the entrances to the buildings should be designed so that their (usable) width is at least $120 \mathrm{~cm}$. If possible, they should be protected from the effects of weather conditions. It should also be ensured that the steps have a suitable profile without undercuts or notches and that balustrades and handrails have a comfortable grip [Nowak 2008]. They should be used on both sides when the height of the stairs exceeds $50 \mathrm{~cm}$ and it is necessary to use intermediate handrails if the width of the flight of stairs exceeds 4 m, every $4 \mathrm{~m}$ maximum [RMI 296 paragraph 3]. Due to visually impaired people, important elements of the stairs are changes in the texture and color of the pavement in the $60 \mathrm{~cm}$ strip before and after the stairs. Thanks to this it is known where the change in height level begins. It is also practiced that all the edges of the steps are marked in a contrasting way. However, it is more important to mark the first and last step of the stairs. An additional auxiliary element is the contrasting color of the handrail, that should run along the entire stairs [Kowalski 2008]. In addition, it should protrude by $30 \mathrm{~cm}$ in the section before and after the stairs. The handrails should be finished in a way ensuring safe use [Nowak 2003]. Their thickness should be $3-5 \mathrm{~cm}$ and height $90 \mathrm{~cm}$ [Meyer-Bohe 1998] (better if it would be double on heights at $75 \mathrm{~cm}$ and $90 \mathrm{~cm}$ ).

Ramps are elements that greatly facilitate, and sometimes even allow at all, to overcome height differences, especially for people with mobility dysfunctions. However, in this case, the design guidelines should be followed. The basic feature of ramps is their slope, and its values are precisely specified in Polish legal acts. The smaller it is, the more convenient it will be to use, but at the same time, a greater distance will have to be traveled by a person moving e.g. in a wheelchair. Similar to stairs, landings should also be used in this case, and the maximum permitted length of the run without using it is $9 \mathrm{~m}$. Dimensions should be taken depending on the location. Landings in front of the door should have a minimum length of $150 \mathrm{~cm}$, and if the location and size of the door require additional maneuvering space, appropriately more. Whereas, landings between ramps should have a minimum size of $150 \times 150 \mathrm{~cm}$ [RMI § 71 ust. 3].

The ramp must not be narrower than $120 \mathrm{~cm}$ and it should be ensured that its edge is limited by the minimum $7 \mathrm{~cm}$ high threshold to exclude the possibility of wheel slip. It is also necessary to design handrails parallel 
to the ground at heights of $75 \mathrm{~cm}$ and $90 \mathrm{~cm}$ on both sides. If any of them are near the wall, a distance of at least $5 \mathrm{~cm}$ should be kept. It is also recommended to roof the ramps and the use of top lighting falling on the running surface with an intensity of at least 100 lux [Budny 2009]. Similarly to stairs, contrasting markings should be introduced at the top and bottom of the driveway, and the beginning and end of the level change should be marked through a different surface texture [Wysocki 2010]. The space for maneuvering $(150 \times 150 \mathrm{~cm})$ before and after the ramp is often forgotten, but it should be designed there [Kowalski 2013].

Attention should also be paid to the mobility difficulties related to crossing high curbs. To overcome such barriers, there are designing curb ramps. The law regulates its maximum slope at $15 \%$. However, guided by the needs of people in wheelchairs, the maximum value should be $5 \%$ and the width minimum of $90 \mathrm{~cm}$. Only height differences that not exceed $2 \mathrm{~cm}$ are allowed [Kowalski 2010]. Car parks are an important element of any housing estate. There should be also designed parking spaces intended for the disabled. They should be located as close as possible to a suitably adapted entrance to the building or when there is no such nearby as close as possible to free exit from the parking lot. The number of spaces reserved for disabled people depends on the size of the car park. Different variants of such parking spaces are provided (Fig. 2). First of all, they should have larger than standard dimensions. Disabled person should be able to leave the vehicle effortless, so a width of $3.6 \mathrm{~m}$ is required [Neufert 2011]. In addition, entering the sidewalk from such a place should take place with avoidance of the road traffic lane [Kowalski 2010].

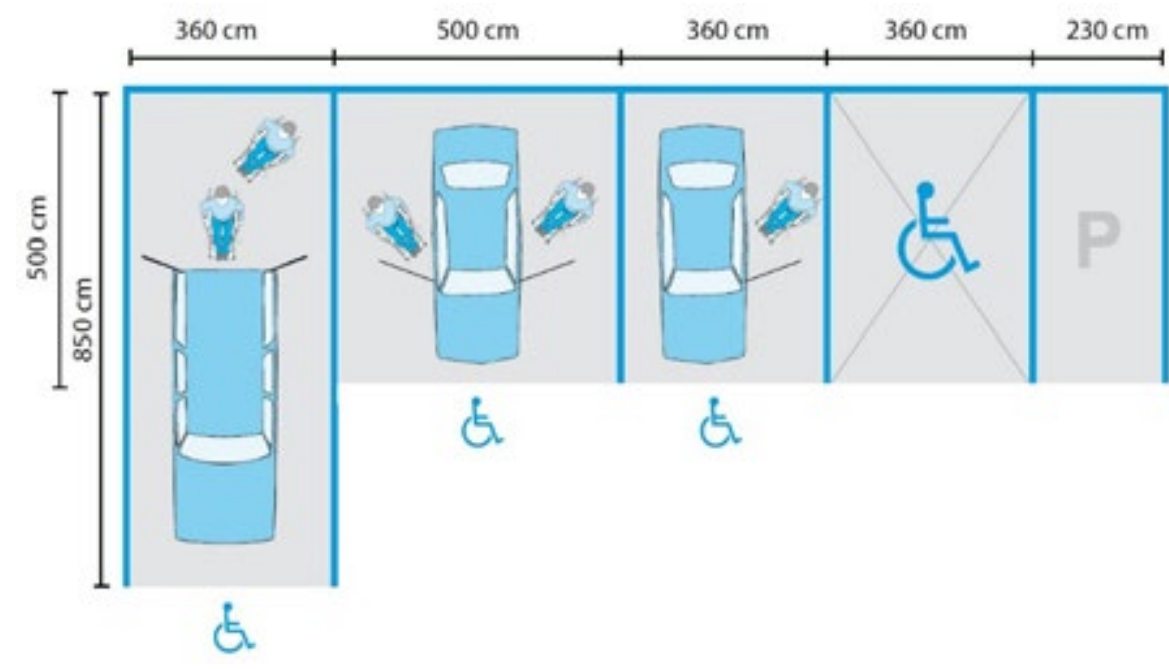

Fig. 2. Dimensions of parking places for disabled (source: Kowalski 2010)

\section{Space equipment}

According to Regulation of the Minister of Infrastructure of 12 April 2002 on the technical conditions that should be met by buildings and their location $\S 40$ ust. 1 :

In a complex of multi-family buildings covered by one building permit, depending on the utility needs, provide playgrounds for the youngest children and recreational places available for the elderly and disabled, with at least 30\% of this area in biologically active area, if not it is determined differently in the decision on building conditions and land development.

From the perspective of planning accessibility, it looks like that when designing such areas, additional space of at least $90 \times 120 \mathrm{~cm}$ should be considered, preferably near the benches. As a result, people in wheelchairs have a place to stay without being isolated from other people using the seating. It should also be ensured that the paths leading from residential buildings to these places are free of curbs and stairs (when possible) [Kowalski 
2011]. When designing pedestrian routes, the principles of accessibility planning described earlier should be also taken into account.

Besides, in spaces that require overcome longer distances seating spaces should be provided at a maximum distance of $30 \mathrm{~m}$. They should be located near the sidewalks, but not directly on them. These places should be planned in such a way that the legs of people using, for example, benches, do not disturb people moving on designated paths [Kowalski 2010]. Park benches should also have appropriate dimensions strictly resulting from ergonomics, which directly reflects into comfort of use. In chapter 9. ADA Standards for Accessible Design from 2010 can be found the recommended bench dimensions. Their length should be at least $1065 \mathrm{~mm}$. The seat should be designed at a height of 430 to $485 \mathrm{~mm}$, while its width (depth) can vary in the range of $510-610 \mathrm{~mm}$. Recommend version is the bench with backrest, which can be shifted back in relative to the end of the seat by a maximum of $64 \mathrm{~mm}$ and start at most $51 \mathrm{~mm}$ above its plane, and end at least $455 \mathrm{~mm}$, which translates into its minimum height $-404 \mathrm{~mm}$. Armrests are not required, but if they do appear, they should be about $205 \mathrm{~mm}$ above the seat, and their width is recommended in the range of $100-130 \mathrm{~mm}^{1}$. In practice, it looks like the benches are usually about $150-180 \mathrm{~cm}$ long and about $90 \mathrm{~cm}$ high. An additional advantage is the appropriate backrest profile and the angle it creates with the seat (it is recommended within $\left.96^{\circ}-98^{\circ}\right)^{2}$.

In a given place there may be some elements of small architecture, such as lighting poles, litter bins, picnic tables, information boards, road signs, bollards, etc. The arrangement of these elements can be problematic, especially for people with sight impairments. Therefore, it is necessary to use the so-called rule of one line. Placing such elements in a straight line parallel to the pavement axis will result in ordering and strengthening its outline. Elements attached to the columns should be directed along the axis of the path so that they do not interfere with the space designated for movement [Centre for Excellence... 2012]. It is recommended that the distance between individual free-standing objects should be at least $120 \mathrm{~cm}$, preferably $150 \mathrm{~cm}$. Moreover, they should contrast with the background [Czarnecki and Siemiński 2004]. Information boards and display cases should be located outside the usable area of the pavement. If any of the elements protrude beyond the facade of building for a minimum of $10 \mathrm{~cm}$ and is placed at a height of between $30-220 \mathrm{~cm}$, a warning element that can be felt with a white cane should be used, along its entire contour [Kowalski 2011] (Fig. 3). If, however, there are drain grates in pedestrian routes, they should be located perpendicular to the direction of moving to prevent stuck of wheelchair wheel. Besides, the maximum opening width can be a maximum of $2 \mathrm{~cm}$ [Czarnecki and Siemiński 2004].

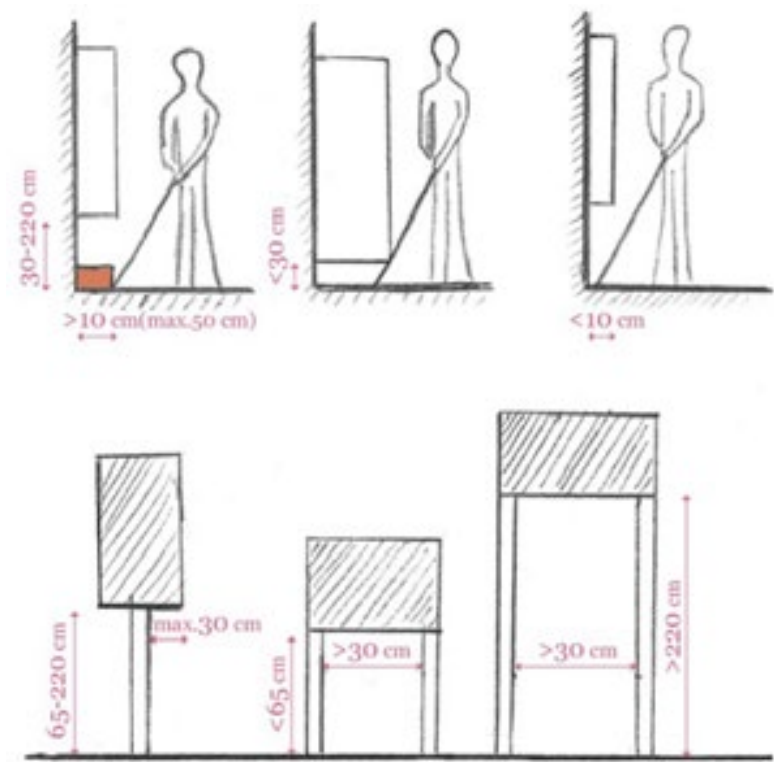

Fig. 3. Rules of safe arrangement of information signs (source: Kowalski 2011) 
In most cases, disability does not disqualify people from being physically active. Of course, this is a kind of obstacle and causes some restrictions, but properly adapted space and devices give them a chance to be active. The most important rule is to follow the same guidelines as for other elements of space. Therefore, appropriate surface should be taken into consideration (sandy surfaces should definitely be avoided), the width of the access to devices, maneuvering spaces in front of them and their dimensions (Fig. 4). It is best if the instructions for using the machine are also written in Braille language. Surfaces on playgrounds should additionally meet the fall prevention standards. It can be e.g. plastic material meeting the HIC criterion (head injury criterion) specified in the PN-EN 1177 standard.

Designing at least some devices suitable for use by people with disabilities in places intended for sports and recreation will have a positive impact on their integration with other residents. The more, some of those devices can also be used by non-disabled people. This is especially important for children who would like to play with their peers.
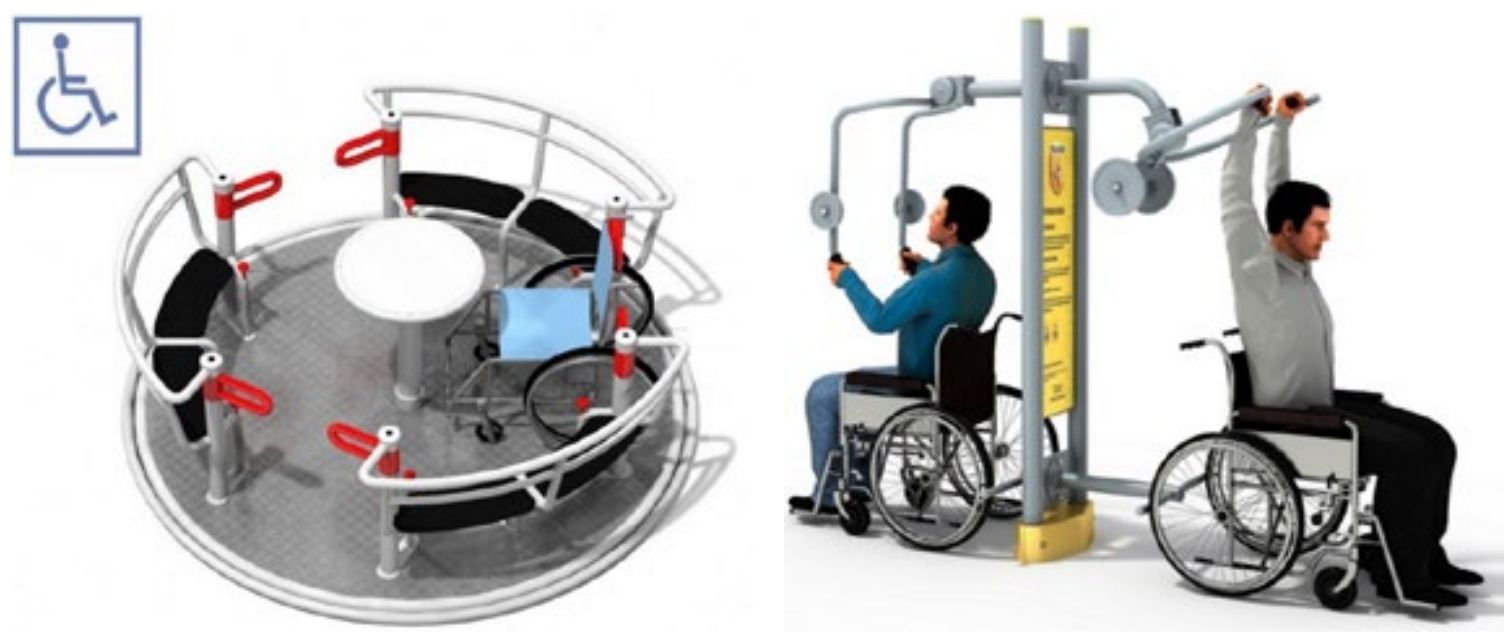

Fig. 4. Examples of devices that can be used by people in wheelchairs (sources: inter-fun.ploferta_szczegoly.html,22,3829 and trainer.net.pl/pl/niepelnosprawni/257-ed-01-a-wyciag-pylon.html)

\section{Conclusion}

In light of the rapidly passing human life, it is easy to attribute architecture to longevity that does not require change. However, it should be remembered that it should be mainly useful for people, especially in the case of housing estates. This translates directly into maintaining appropriate standards that change with social evolution. Therefore, living spaces should be constantly modernized to keep up with development or go even ahead of it to some extent. However, this requires appropriate financial outlays, which may prove to be a barrier that cannot be overcome [Wyżkowski et al. 2004]. By increasing the accessibility of housing estate, it can significantly contribute to reducing the fear of disabled people about social exclusion and improving their quality of life [Borowiecki 2016]. The cooperation of aspects such as interpersonal integration, properly shaped surroundings and elements supporting the movement, reflect directly into the improvement of their quality of life on many levels. Thanks to this, they have a better chance to shape their lives freely and independently [Kuldshun and Rossmann 1980]. 


\section{References}

[1] 2010 ADA Standards for Accessible Design

[2] Adach-Stankiewicz E., i in., 2012. Narodowy Spis Powszechny Ludności i Mieszkań 2011, Raport z wyników, Zakład Wydawnictw Statystycznych, Warszawa.

[3] Barker P., et al. 1995. Building Sight, Royal National Institute for the Blind, London.

[4] Błądek Z., 2003. Hotele bez barier, Albus, Poznań.

[5] Borowiecki P., 2016. Jakość życia osób z niepełnosprawnościa i ich rodzin w perspektywie zewnętrznej i wewnętrznej-przegląd wybranych badań, [w:] „Niepełnosprawność: zagadnienia, problemy, rozwiązania” Nr III/2016(20), PFRON, Warszawa.

[6] Budny J., 2009. Dostosowanie budynków użyteczności publicznej - teoria i narzędzia, Stowarzyszenie Przyjaciół Integracji, Warszawa.

[7] Centre for Excellence in Universal Design, 2012. Building for Everyone: A Universal Design Approach, External environment and approach, National Disability Authority, Dublin.

[8] Czarnecki B., Siemiński W., 2004. Kształtowanie bezpiecznej przestrzeni publicznej, Difin, Warszawa.

[9] Gołuch A., 1995. Budownictwo dla osób upośledzonych fizycznie i inwalidów, Kanon, Gdańsk.

[10] Grandjean E., 1987. Ergonomia Mieszkania, aspekty fizjologiczne i psychologiczne w projektowaniu, Arkady, Warszawa.

[11] Jasiak A., Swereda D., 2009, Ergonomia osób niepełnosprawnych, Wydawnictwo Politechniki Poznańskiej, Poznań.

[12] Kowalski K., 2008. Mieszkanie dostępne dla osób z dysfunkcjami wzroku, Stowarzyszenie Przyjaciół Integracji, Warszawa.

[13] Kowalski K., 2010. Projektowanie bez barier - wytyczne, Stowarzyszenie Przyjaciół Integracji, Warszawa.

[14] Kowalski K., 2011. Planowanie Dostępności. Prawo w praktyce, Stowarzyszenie Przyjaciół Integracji, Warszawa.

[15] Kowalski K., 2013. Planowanie dostępności - polskie uwarunkowania prawne i praktyka, [w:] „Niepełnosprawność: zagadnienia, problemy, rozwiązania" Nr I/2013(6), PFRON, Warszawa.

[16] Kuldschun H., Rossmann E., 1980. Budownictwo dla upośledzonych fizycznie - projektowanie obiektów i urządzeń, Arkady, Warszawa.

[17] Meyer-Bohe W., 1998. Budownictwo dla osób starszych i niepetnosprawnych, Arkady, Warszawa.

[18] Neufert E., 2011. Podręcznik projektowania architektoniczno-budowlanego, Arkady, Warszawa.

[19] Nowak B, 2003. Niepetnosprawni, wymagania techniczno-budowlane, Państwowa Inspekcja Pracy, Warszawa 2003.

[20] Nowak E., et al., 2008. Mieszkanie dostępne dla osób z dysfunkcją narządu ruchu, Stowarzyszenie Przyjaciół Integracji, Warszawa.

[21] Pallado J., 2007. Architektura wielorodzinnych domów dostępnych, Wydawnictwo Naukowe Śląsk, Katowice.

[22] Pawłowska K., 2001. Idea swojskości miasta, Wydawnictwo Politechniki Krakowskiej, Kraków.

[23] Rozporządzenie Ministra Infrastruktury z dnia 12 kwietnia 2002 r. w sprawie warunków technicznych, jakim powinny odpowiadać budynki i ich usytuowanie (Dz.U. 2002 Nr 75 poz. 690, z późniejszymi zmianami).

[24] Ujma-Wąsowicz K., 2005. Ergonomia w architekturze, Wydawnictwo Politechniki Śląskiej, Gliwice.

[25] Ustawa Prawo Budowlane z dnia 7 lipca 1994 roku (Dz.U. 1994 nr 89 poz. 414 z późniejszymi zmianami).

[26] Wiciak J., et al., 2012. Niewidomi w dużym mieście, Wydawnictwo AGH, Kraków.

[27] Wysocki M., 2010. Projektowanie otoczenia dla osób niewidomych. Pozawzrokowa percepcja przestrzeni, Wydawnictwo Politechniki Gdańskiej, Gdańsk 2010.

[28] Wysocki M., 2012. Standardy dostępności dla miasta Gdyni, Gdynia 2012.

[29] Wyżkowski A., et al., 2004. Przestrzeń bezpieczna, Wydawnictwo Politechniki Krakowskiej, Kraków.

[30] Złowodzki M., 2008. O ergonomii i architekturze, Wydawnictwo Politechniki Krakowskiej, Kraków.

\section{Websites}

[1] eBIFRON NUMER 1/2012 - ABC osoby niepetnosprawnej, Bariery do pokonania, http://www.pfron.org.pl/ebi/poprzednie-wydania/numer-12012-abc-osoby/pomoc-osobie-niepelnos/53,Barierydopokonania.html (dostęp: 25.10.2016)

[2] http://kostkabrukowa.buszrem.pl/projects/schody-w-ogrodzie/ (dostęp: 04.02.2017)

[3] http://ladnydom.pl/Ogrody/1,113380,16780740,Lawka_w_ogrodzie.html (dostęp: 05.02.2017)

[4] http://www.ehow.com/info_8707000_dimensions-outdoor-benches.html (dostęp: 05.02.2017) 


\section{Ludzie niepełnosprawni w przestrzeniach osiedlowych}

Streszczenie: Wiele uwagi poświęca się przystopowaniu budynków użyteczności publicznej, czy też transportu dla osób niepełnosprawnych. Niewiele natomiast przestrzeniom, od których podróż w dane miejsce docelowe się rozpoczyna. Droga, jaką należy pokonać momentu opuszczenia własnego mieszkania, aż do dojścia do komunikacji miejskiej może znacząco utrudnić życie osobom o ograniczonej mobilności. Osiedle mieszkaniowe jest również miejscem, gdzie ludzie spędzają dużą część swojego czas wolnego. Dlatego, aby nie wykluczać z życia społecznego osób niepełnosprawnych, projektowanie takich miejsc w sposób dostępny jest niezmierne istotne. Właśnie to zagadnienie zostało poruszone w niniejszym artykule.

Słowa klucze: dostępność, projektowanie uniwersalne, ludzie niepełnosprawni, osiedla mieszkaniowe 